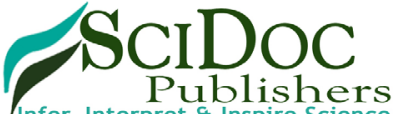

Publishers

\title{
Spoilage Potentials of Biodeteriogens on Two Edible Oils - Groundnut (Arachis Hypogaea) and Palm (Elaeis Guineensis) Oil Sold in Rumuowoji Ultra - Modern Market, Port Harcourt, Nigeria
}

Research Article

\author{
Odili Chukwudi ${ }^{1}$, Anthony A. Ibiene ${ }^{1}$, Dinebari P. Berebon ${ }^{2 *}$, Christopher O. Eze ${ }^{2}$, Ezinnwanne C. Ezeibe ${ }^{2}$, Anthony I. Onah ${ }^{2}$
}

${ }^{1}$ Department of Microbiology, Faculty of Science, University of Port Harcourt, P.M.B. 5323, Choba, Port Harcourt, Nigeria

${ }^{2}$ Department of Pharmaceutical Microbiology and Biotechnology, Faculty of Pharmaceutical Sciences, University of Nigeria, Nsukka, 410001, Enugu State, Nigeria.

\section{Abstract}

The spoilage potential and physicochemical characteristics of biodeteriogens on edible oils (groundnut oil and palm oil) sold in the market (Rumuowoji ultra-modern market) within Port Harcourt were examined. Spoilage bacterial genera were identified as Bacillus spp, Pseudomonas spp, Micrococcus spp and Staphylococcus spp while the fungal genera were identified as Aspergillus spp, Penicillium spp and Fusarium spp. The screen test for the utilization of the oil samples by the biodeteriogens showed that 7 out of the 9 bacterial species and 4 out of the 5 fungal species were capable of utilizing the edible oils as sole source of carbon and energy. Utilization of both oils by the mixed bacterial cultures of Bacillus spp. A1, Psendomonas spp. A2, Bacillus spp. B1 and Staphylococcus spp. B3 resulted in maximum increases in total viable counts (TVC) of $1.5 \times 10^{8} \mathrm{cfu} / \mathrm{ml}$ as optical density (OD) increases to $1.31 \mathrm{~nm}$ while $\mathrm{pH}$ decreases with time from 7.10 - 5.65 over a 20 days' incubation. Similarly, the TVC, OD and pH of the mixed fungal culture of Aspergillus spp $\mathrm{Af}_{3}$, Aspergillus $s p p \mathrm{Bf}_{1}$ and Penicillium $s p p \mathrm{Bf}_{2}$ on palm oil and groundnut oil where: $1.09 \times 10^{6} \mathrm{cfu} / \mathrm{ml}, 1.01 \mathrm{~nm} ; 7.0-6.0$ and $0.9 \times 10^{5} \mathrm{cfu} / \mathrm{ml}, 0.81 \mathrm{~nm}, 7.2-6.1$ respectively. The physiochemical analyses of the palm oil samples revealed that the highest mean free fatty acid (FFA) content and the peroxide value (PV) were $5.08 \%$ and 7.98 $\mathrm{mEq} / \mathrm{kg}$ respectively in palm oil samples inoculated with mixed bacterial culture.

Keywords: Biodeteriogens; Edible Oils; Spoilage and Physicochemical Characteristics.

\section{Introduction}

Edible oil is not a sterile product. The micro flora of edible oil reflects the quality of oil, the sanitary conditions of processing equipment used to manufacture the oil as well as the environmental and sanitary conditions during packaging and handling of such product [1]. Fat and oil which are naturally occurring constituents of edible oil are subject to microbial deterioration. Essential fatty acids (EFAs) which are naturally occurring constituents of edible oil have been considered as functional food and nutraceuticals. Beside their use in the production of soap and other surface-active molecules, fat and oil are increasingly used as a source of fuel energy producing purposes in automobiles, trains, aeroplanes or boats, or the direct production of biodiesel [2]. These new uses underlie the food versus fuel debate of edible oil [3].

Both groundnut oil and palm oil are the primary sources of edible oils used in most household in Nigeria. Currently, Nigeria is the fifth world leading producers of palm oil after Columbia, Thailand, Malaysia and Indonesia being the first [4]. Unlike groundnut oil, palm oil is rich in palmitic acid with a reddish brown color impacted by $\beta$ - carotene. Edible fats and oils usually referred to as lipids contain $95-98 \%$ triacylglycerols, lesser percentages of diacyl- and mono-acylglycerols, free fatty acids, and $1-2 \%$ of nonsaponifiable components, such as sterols, tocopherols, and color compounds [5].

Edible oils are known to support the growth of bacteria, fungi and molds especially when they contain moisture. The composition of these oils determines the extent and type of organisms likely to thrive in them. These organisms cause chemical changes that lead to deterioration in the quality of the oils.

Although several researchers have reported the quality assess-

*Corresponding Author:

Dinebari P. Berebon,

Department of Pharmaceutical Microbiology and Biotechnology, Faculty of Pharmaceutical Sciences, University of Nigeria, Nsukka, 410001, Enugu State, Nigeria.

Tel: 08064696374

E-mail: dinebari.berebon@unn.edu.ng

Received: July 14, 2020

Accepted: August 04, 2020

Published: August 06, 2020

Citation: Odili Chukwudi, Anthony A. Ibiene, Dinebari P. Berebon, Christopher O. Eze, Ezinnwanne C. Ezeibe, Anthony I. Onah. Spoilage Potentials of Biodeteriogens on Two Edible Oils - Groundnut (Arachis Hypogaea) and Palm (Elaeis Guineensis) Oil Sold in Rumuowoji Ultra - Modern Market, Port Harcourt, Nigeria. Int J Food Sci Nutr Diet. 2020;9(5):470-476. doi: http://dx.doi.org/10.19070/2326-3350-2000083

Copyright: Dinebari P. Berebon ${ }^{\circ} 2020$. This is an open-access article distributed under the terms of the Creative Commons Attribution License, which permits unrestricted use, distribution and reproduction in any medium, provided the original author and source are credited. 
ment of palm oil produce marketed within some states of Nigeria: Abia State [6], Anambra State [7], Delta State [8], Ibadan [9], Kogi State [10] and Rivers State [11]; such report indeed represented a fractional totality of the quality assessment of palm oil sold in such states. It is thus pertinent to further investigate other unexplored or un-sampled regions within the states to provide a more accurate baseline data on the quality of palm oil on sale in its markets. Thus, this study is aimed at examining the potential biological contaminants (bacteria and fungi) contaminating edible oils (groundnut oil and palm oil) sold in the market (Rumuwoji Ultra-modern market) within Port Harcourt as well as their physicochemical characteristics.

\section{Materials And Methods}

\section{Collection of Samples}

Samples of the edible oils (palm oil and groundnut oil) were obtained from Rumuwoji Ultra-Modern Market (Mile One), Port Harcourt. The samples were collected in sterile universal bottles. Care was taken not to contaminate the bottles before and during collection of the samples. The samples were taken to the laboratory for microbiological and physicochemical analyses.

\section{Isolation of biodeteriogens}

Enrichment and pour plate technique was adopted for the isolation of bioteriogens in the oil samples. Five drops of each type of oil were added to $10 \mathrm{ml}$ of nutrient broth and incubated at room temperature for $48 \mathrm{~h}$. Following this enrichment, a 10-fold serial dilution of the culture was performed using sterile physiological saline as diluent and $100 \mu$ l of appropriate dilutions plated on nutrient agar and potato dextrose agar (PDA). Nutrient agar and PDA were each fortified with $50 \mathrm{mg} / \mathrm{l}$ of nystatin and chloramphenicol to inhibit the growth of fungi and bacteria respectively. Pour plate method was adopted for isolation. Nutrient agar plates and PDA plates were incubated at room temperature $37^{\circ} \mathrm{C}$ for 24-48 $\mathrm{h}$ and $25^{\circ} \mathrm{C}$ for 3-5 days respectively. The bacterial colonies which developed on the nutrient agar plates were picked and subcultured on fresh nutrient agar plates using the streak plate technique for discrete colonies of bacteria. The fungal colonies which developed on the PDA plates were also picked and sub-cultured on fresh PDA plates using a sterile inoculating needle for discrete colonies of fungi.

\section{Characterization and identification of the isolates}

The bacterial isolates were characterized and identified based on their morphological and biochemical characteristics. Gram staining, spore stain, oxidase test, catalase test, coagulase test, methyl red and Voges-Proskauer (MRVP) test, indole test, citrate test, motility test, sugar fermentation test and triple sugar iron agar (TSIA) test were all carried using standard microbiological procedures. Macroscopic and Microscopic examination were used for the characterization and identification of fungal isolates. The later was done by needle mount method.

\section{Screen test for utilization of the edible oils}

The organisms (bacteria and fungi) isolated from an oil (groundnut oil or palm oil) were tested for utilization of the oil using a modified mineral salts medium [12] containing the oil as sole source of carbon and energy. The medium was dispensed in 9.9 $\mathrm{ml}$ amounts in test tubes. To half of these tubes were added $0.1 \mathrm{ml}$ each of groundnut oil and to the remaining tubes were added 0.1 $\mathrm{ml}$ each of palm oil. After capping, all the tubes were sterilized by autoclaving at $121^{\circ} \mathrm{C}$ for 15 minutes and allowed to cool. Upon cooling, each set of tubes were inoculated with an isolate from the oil. Two control tubes (one containing groundnut oil and the other palm oil) remained uninoculated. All the tubes were incubated at room temperature for 14 days. Each tube was checked for turbidity after the incubation period.

\section{Monitoring the Growth of the Isolates in the oil Samples}

A modified mineral salts medium [12] was prepared and dispensed in $99 \mathrm{ml}$ quantities into $250 \mathrm{ml}$ Erlenmeyer flasks. To each of these flasks were added $1 \mathrm{ml}$ each of fresh oil. The mixture was autoclaved at $121^{\circ} \mathrm{C}$ for 15 minutes. Isolates that showed highest turbidity in the screen test were used as mixed cultures to inoculate flasks containing that oil. Two flasks (one containing groundnut oil and the other palm oil) remained uninoculated and served as controls. The flasks were incubated at room temperature on a rotary shaker incubator (Staurt orbital incubator, S150, OSA, UK) operated at $120 \mathrm{rpm}$ for 20 days. The optical density (OD) at $560 \mathrm{~nm}$, total viable counts (TVC) and $\mathrm{pH}$ of the culture in each flask were monitored periodically at intervals of 4 days. The optical density (OD) at $560 \mathrm{~nm}$ was measured using spectrophotometer (spectrumlab 7525). Total viable counts were obtained from nutrient agar plates and potato dextrose agar plates for bacteria and fungi respectively after serial dilution in sterile physiological saline. The $\mathrm{pH}$ of the culture was measured using a $\mathrm{pH}$ meter equipped with glass electrode.

\section{Extraction and Gas Chromatography}

The remaining oils in the mineral salt medium at the end of the incubation period were extracted in order to determine the extent of biodeterioration by the isolates. The extraction was performed by adding $10 \mathrm{ml}$ of thoroughly shaken medium containing the residue of the oil to a separating funnel. To this was added $10 \mathrm{ml}$ of n-heptane. The funnel was vigorously shaken, and the contents were allowed to settle in order for the phases to separate. Upon separation, the solvent layer was drawn off into a clean glass vial. The aqueous phase was further mixed with $5 \mathrm{ml}$ fresh solvent and the extraction procedure was repeated. The two extracts were pooled and stored in the refrigerator $\left(4^{\circ} \mathrm{C}\right)$ until ready for analysis. The extracts were then analyzed using a computerized gas chromatography equipped with a flame ionization detector (FID).

\section{Determination of physicochemical characteristics of the oil samples}

The free fatty acid (FFA) content and peroxide value (PV) of the unionoculated and inoculated oil samples were determined according to the methods described [13].

\section{Statistical analyses}

All data were represented are means of duplicates and values subjected to statistical analysis using SPSS 20. Data were represented with graphs and tables. 


\section{Results And Discussions}

Biodeteriogens of edible oil are consortia of microorganisms which cause spoilage while utilizing the oil or its constituents as a substrate - source of carbon and energy. The results indicated that bacteria, fungi and molds are the potential biodeteriogens of edible oil. A summary of the microbial isolates from palm oil and groundnut oil is presented in Table 1. The bacteria identified were members of the following genera: Bacillus spp, Pseudomonas $s p p$, Micrococcus spp and Staphylococcus spp while fungal genera identified were Aspergillus spp, Penicillium spp and Fusarium spp. These bacteriogens have previously been implicated in spoilage of vegetable oils and palm oil sold within Amassoma, Bayelsa State [14], Jos Metropolis [15, 16]. Interestingly, Bacillus, Pseudomonas and Staphylococcus were found to contaminate both oils. Micrococcus was found to contaminate palm oil only. It was observed from this study that the predominant bacterial flora were Gram positive bacteria. Some of these bacteria are pathogenic and can cause food poisoning. Their presence in the edible oils may be due to chance contamination during handling or storage and biofouling of processing equipment in contact with the oil.

The results of the screen test for the utilization of the two edible oils as sole source of carbon and energy by the bacterial and fungal isolates are presented in Table 2 and 3 respectively. Some of the isolates did not produce turbidity in the mineral salt broth cultures. Those cultures that did not show any turbidity were restreaked out on nutrient agar plates and PDA plates for bacteria and fungi respectively to check for viability. Growth occurred in all the plates inoculated indicating that the organisms were still viable but could not utilize the oils as sole carbon and energy sources for growth. Five out of the 9 bacterial species and 4 out of the 5 fungal species were capable of growing and utilizing the edible oils as sole source of carbon and energy. This suggests that the remaining species were merely chance contaminants and might not have significant spoilage activity on the oils.

Figures 1 and 2 shows the result of the growth patterns of the mixed cultures determined by monitoring the optical density (OD), total viable counts (TVC) and $\mathrm{pH}$ of the cultures utilizing the two oils as sole carbon and energy sources. The cultures showed that as the TVC increased, there were corresponding increases in $\mathrm{OD}$ and decreases in $\mathrm{pH}$ with time. The utilization of the edible oils as sole source of carbon and energy by the organisms resulted in their growth with a concomitant production of acidic metabolites. These acidic metabolic products might account for the decreases in $\mathrm{pH}$ of the cultures. Organoleptic changes and increase in acidity may result when oils are metabolized by microorganisms. It was further observed in Figures 1 and 2 that the cultures had reached the stationary phase of growth. This observation is attributed to the rate of utilization of the two oils by the microorganisms and the stability of these oils to microbial spoilage. The results showed that palm oil supported the highest microbial cell growth while groundnut oil supported the least cell growth. These results indicated that groundnut oil was the most stable to microbial spoilage while palm oil was the least biostable.

The results of the free fatty acid (FFA) content ranged from 0.22 - $5.08 \%$ in the uninoculated groundnut oil and inoculated palm oil samples as presented in Table 4. The result showed that there was an increase in FFAs content of the oils at the end of the incubation period. High concentrations of FFAs are undesirable in edible oils as it reduces the palatability and the shelf-life of the oil [17]. This elevation of FFAs is an indication of contamination of the oil by the biodeteriogens. Palm oil inoculated with a mixed bacterial culture has the greatest FFA increase of $5.08 \%$ followed by palm oil inoculated with a mixed fungal culture with a FFA increase of $4.87 \%$. Groundnut oil inoculated with a mixed bacterial culture had a FFA increase of $0.87 \%$. Groundnut oil in-

Table 1. Microbial isolates from palm oil and groundnut oil.

\begin{tabular}{|c|c|c|c|}
\hline \multicolumn{2}{|c|}{ Palm oil } & \multicolumn{2}{c|}{ Groundnut oil } \\
\hline Bacteria & Fungi & Bacterial & Fungi \\
\hline Bacillus spp (2) & Aspergillus spp (2) & Bacillus spp (1) & Aspergillus spp (1) \\
\hline Pseudomonas spp (1) & Fusarium spp (1) & Pseudomonas spp (1) & Penicillium spp (1) \\
\hline Micrococcus spp (1) & & Staphylococcus spp (2) & \\
\hline Staphylococcus spp (1) & & & \\
\hline
\end{tabular}

Legend: Numbers in parenthesis represented the number of microbial species isolated.

Table 2. Screen test for the utilization of the two oils by the bacterial isolates.

\begin{tabular}{|c|c|c|c|c|c|}
\hline Palm oil isolates & $\begin{array}{c}\text { Isolate } \\
\text { code }\end{array}$ & $\begin{array}{c}\text { Palm oil } \\
\text { utilization }\end{array}$ & $\begin{array}{c}\text { Groundnut oil } \\
\text { isolates }\end{array}$ & $\begin{array}{c}\text { Isolate } \\
\text { code }\end{array}$ & $\begin{array}{c}\text { Groundnut oil } \\
\text { utilization }\end{array}$ \\
\hline Bacillus $\mathrm{spp}$ & $\mathrm{A}_{1}$ & +++ & Bacillus $\mathrm{spp}$ & $\mathrm{B}_{1}$ & +++ \\
\hline Pseudomons $\mathrm{spp}$ & $\mathrm{A}_{2}$ & +++ & Staphylococcus $\mathrm{spp}$ & $\mathrm{B}_{2}$ & - \\
\hline Micrococcus $\mathrm{spp}$ & $\mathrm{A}_{3}$ & - & Staphylococcus $\mathrm{spp}$ & $\mathrm{B}_{3}$ & +++ \\
\hline Staphylococcus $\mathrm{spp}$ & $\mathrm{A}_{4}$ & + & Pseudomonas $\mathrm{spp}$ & $\mathrm{B}_{4}$ & + \\
\hline Bacillus $\mathrm{spp}$ & $\mathrm{A}_{5}$ & ++ & & & \\
\hline
\end{tabular}

Legend: - No observable growth; + poor growth; ++ moderate growth and +++ heavy growth 
Table 3. Screen test for the utilization of the two oils by the fungal isolates.

\begin{tabular}{|c|c|c|c|c|c|}
\hline $\begin{array}{c}\text { Palm oil } \\
\text { isolates }\end{array}$ & $\begin{array}{c}\text { Isolate } \\
\text { code }\end{array}$ & $\begin{array}{c}\text { Palm oil } \\
\text { utilization }\end{array}$ & $\begin{array}{c}\text { Groundnut oil } \\
\text { isolates }\end{array}$ & $\begin{array}{c}\text { Isolate } \\
\text { code }\end{array}$ & $\begin{array}{c}\text { Groundnut oil } \\
\text { utilization }\end{array}$ \\
\hline Fusarium spp & $\mathrm{Af}_{1}$ & + & Aspergillus $\mathrm{spp}$ & $\mathrm{Bf}_{1}$ & ++ \\
\hline Aspergillus spp & $\mathrm{Af}_{2}$ & - & Penicillium $\mathrm{spp}$ & $\mathrm{Bf}_{2}$ & ++ \\
\hline Aspergillus $\mathrm{spp}$ & $\mathrm{Af}_{3}$ & +++ & & & \\
\hline
\end{tabular}

Legend: - No observable growth; + poor growth; ++ moderate growth and +++ heavy growth

Figure 1. Growth patterns of a mixed bacterial culture of Bacillus spp $\mathrm{A}_{1}$, Pseudomonas spp $\mathrm{A}_{2}$, Bacillus spp $\mathrm{B}_{1}$ and Staphylococcus spp $B_{3}$ on (a) palm oil and (b) groundnut oil.
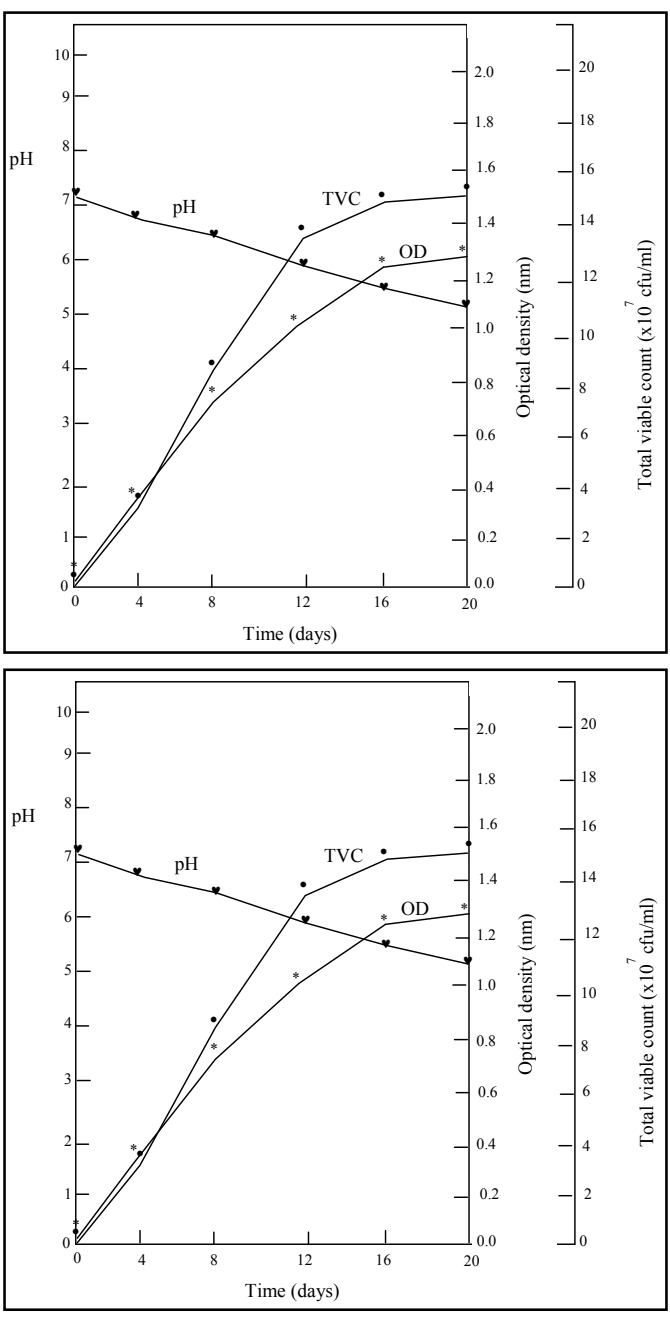

oculated with a mixed fungal culture has the least free fatty acid increase of $0.74 \%$. This results corroborated with other findings [18] who observed that palm oil marketed in Ibadan is hard as their FFAs exceeded 5\% as well as greater than the reported 2.86 to $2.97 \mathrm{mg} / \mathrm{g}, 2.73$ to $2.89 \mathrm{mgKOH} / \mathrm{g}, 2.67$ to $4.20 \%$ and 2.73 to $2.83 \mathrm{mg} \mathrm{KOH} / \mathrm{g}$ obtained in palm oil samples from Delta State, Jos metropolis in Plateau State, Ihiala Local Government of Anambra State and Abia State as reported $[6,7,8,16]$, respectively.

These differences in the biochemical pattern of the organisms on the oils may be related to the differences in the fatty acid composition of the oils. Fatty acids play a very important role in fats and oils because of their health implications in the human diet and properties in industrial processes. The type of fatty acid determines the nutritional status and storability (keeping quality) of the oil. The major fatty acids predominant in palm oil being oleic and palmitic acids. Palmitic acid increases in palm oil are mostly associated with oils produced from over ripe, bruised and crushed fruits, fruits subjected to severe impacts from loading and off-loading bunches and oils stored over long periods [19-21]. Groundnut oil has a high proportion of oleic acid [22]. The palm oil sample (inoculated and uninoculated) has the greatest FFA and account for why it was the least biostable.

The PV of the groundnut oil inoculated with mixed fungal culture and palm oil with a mixed bacterial culture ranged from $4.92-7.98 \mathrm{mEq} / \mathrm{kg}$ as shown in Table 4. This PV ranges are acceptable since they are lower related to the standard value of 10 $\mathrm{mEq} / \mathrm{kg}$ for vegetable oil deterioration as specified by the standard guidelines set by NAFDAC and CODEX [23-25]. Table 4 further shows that at the end of the incubation period, there was an increase in the peroxide value of the inoculated oils. The PV 


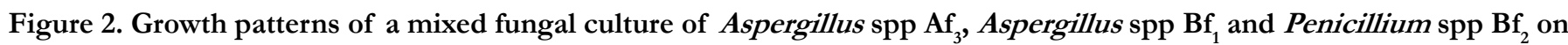
(a) palm oil and (b) groundnut oil.
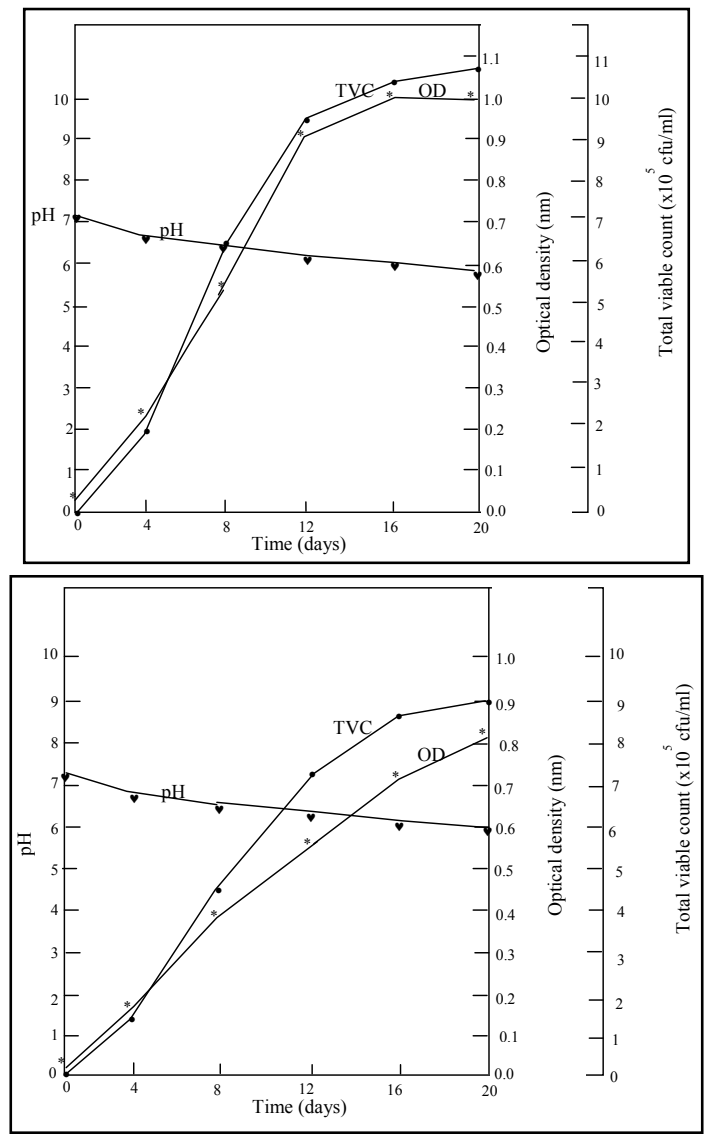

Tables 4: Physiochemical parameters of the uninoculated and inoculated oil samples.

\begin{tabular}{|c|c|c|}
\hline \multirow{2}{*}{ Sample } & \multicolumn{2}{|c|}{ Mean value } \\
\cline { 2 - 3 } & $\begin{array}{c}\text { Free fatty Acid } \\
\text { (FFA)(\%) }\end{array}$ & $\begin{array}{c}\text { Peroxide value } \\
\mathbf{( P V )}(\mathbf{m E q} / \mathbf{k g})\end{array}$ \\
\hline Uninoculated palm oil & 4.01 & 7.11 \\
\hline Inoculated palm oil using a mixed bacterial culture & 5.08 & 7.98 \\
\hline Inoculated palm oil using a mixed fungal culture & 4.87 & 7.65 \\
\hline Uninoculated groundnut oil & 0.22 & 4.54 \\
\hline Inoculated groundnut oil using a mixed bacterial culture & 0.87 & 5.07 \\
\hline Inoculated groundnut oil using a mixed fungal culture & 0.74 & 4.92 \\
\hline
\end{tabular}

is an index that measures the degree to which the oil has undergone rancidity or oxidation indicative of microbial growth. Palm oil samples obtained from red and yellow fruits of the dura variety had higher perioxide value due to microbial growth [26]. The peroxide value determines the degree of oxidation of oil as well as gives an indication of the level of deterioration of oils and fats [27]. It was earlier observed that lipolytic fungi while contributing to the deterioration of vegetable oil by increasing the amount of free fatty acid, do not effect the oxidation state of the oil [22]. This observation might be responsible for the low peroxide value increase recorded in groundnut oil using a mixed fungal culture in this study.

The chromatographic tracings of the methylated heptane extracts of the two oils are presented in Figures 3 and 4. The figures revealed that the inoculated oils showed a reduction in the sizes of peaks when compared to their uninoculated oils. The reduction recorded in the sizes of the peaks is a clear indication that the components of the oils were utilized and degraded by the isolates.

Bacteria were the predominant organisms isolated from this study. There was preponderance of bacteria over fungi in this study. Some of the microorganisms isolated can cause health problems in individuals who consume the product without heat processing. Some are food spoilage organisms and may accelerate the deterioration of the oils.

Some Bacillus species are pathogenic and can cause food poisoning. Their presence in the oil samples may be due to the exposure of the oil sample to the spores of the organism which are dormant and are highly resistant to the lethal effects of heat drying and ultraviolet radiation. Bacillus species has versatile intrinsic deterioration potentials due to production of protease and lipases that are stable at high temperature, at alkaline $\mathrm{pH}$ and in the presence of 
Figure 3. Gas chromatographic profiles of fatty acid components of (a) uninoculated palm oil (Baseline), (b) uninoculated palm oil (control), (c) inoculated palm oil using a mixed bacterial culture and (d) inoculated palm oil using a mixed fungal culture.

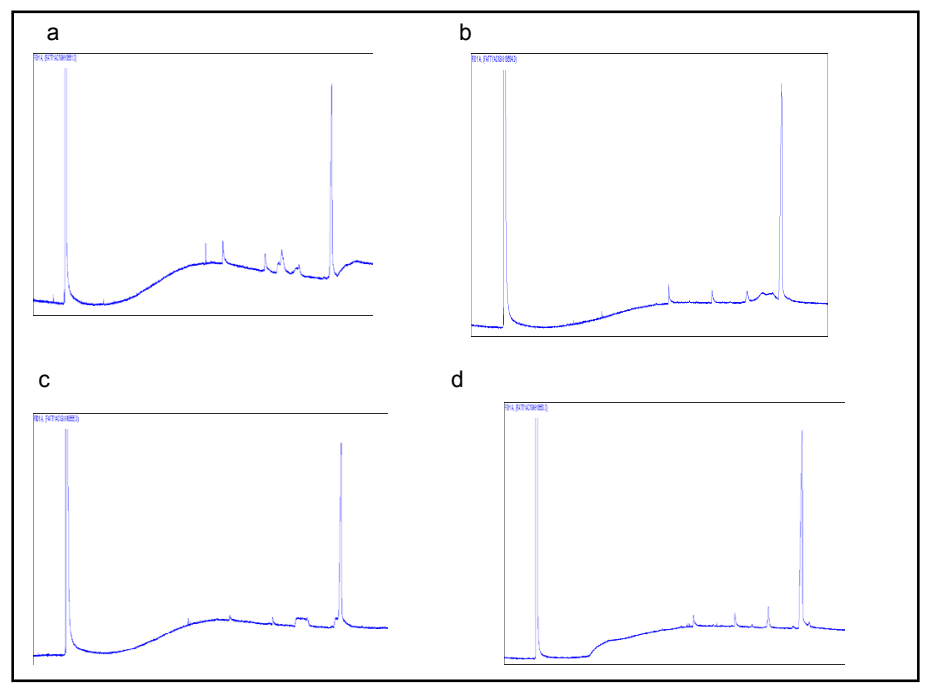

Figure 4. Gas chromatographic profiles of fatty acid components of (a) uninoculated groundnut oil (Baseline), (b) uninoculated groundnut oil (Control) (c) inoculated groundnut oil using a mixed bacterial culture and (d) inoculated groundnut oil using a mixed fungal culture.

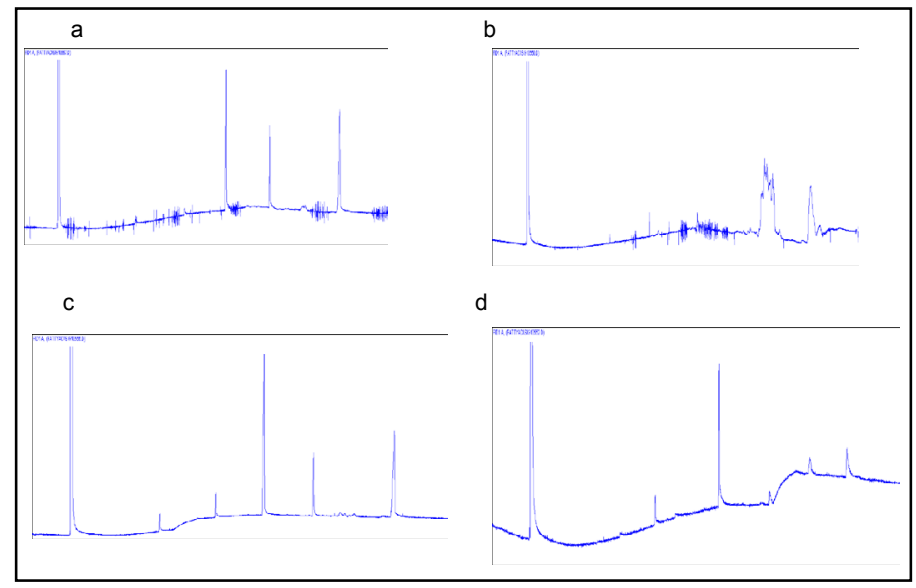

detergents, tolerance to high $\mathrm{pH}$ concentrations, oil and grease as well as biofilms formation potentials. Some species of Staphylococcus are capable of producing enterotoxin and are noted to survive for extended periods in hostile environments. They could cause gastroenteritis in the individual if the oil is consumed raw. Their isolation could be an indication of unhygienic handling of the oils by the sellers or contamination during production cycle.

Species of Aspergillus, Penicillium and Fusarium are of health significance because they are known to produce toxin. These fungi produce a group of toxic metabolites known as aflatoxin which is capable of inducing toxic syndromes especially cancer. Since deteriorated edible oils pose certain health risk, there is need to prevent factors that could cause their deterioration.

This study revealed that palm oil was the least biostable to microbial deterioration while groundnut oil was the most biostable. However, this can be attributed to the differences in the intrinsic and extrinsic requirements of microorganisms and hence microbial utilization of the constituents of the oil.

\section{Conclusion}

Microbial deterioration of edible oils is greatly dependent on the microbial species capable of utilizing the fatty acid components of the oils as their sole source of carbon and energy. Palm oil was found to contain the highest number of microbial species and supported the highest cell growth compared to groundnut oil. The presence of the microbial species in the oil samples may be due to contamination during harvesting, processing, handling and storage. The scale of operations differs and this affects the quality of the final product. Apart from fouling the organoleptic properties of the edible oil, these biodeteriogens ferment components of the oil to produce toxic chemicals or toxins detrimental to human consumption if not evaluated for microbial quality.

\section{References}

[1]. World health organization. Food safety and food borne diseases and value chain management for food safety. "Forging links between agriculture and health" CGIAR on agriculture and health meeting in WHO/HQ; 2007.

[2]. Gunstone FD. Composition and properties of edible oils. Edible oil process- 
ing. 2000:1-33.

[3]. Gunstone FD. The food-fuel debate. Vegetable Oils In Food Technology. 2nd edn. Oxford, UK. 2011; 2: 19-21.

[4]. Sawe BE. Top Palm Oil Producing Countries In The World. Retrieved August. 2018; 19: 2019.

[5]. Kochhar P. Thermal Stability of Fats for High Temperature Applications. Functional Dietary Lipids. Woodhead Publishing. 2016; 103-148.

[6]. Udensi EA, Iroegbu FC. Quality assessment of palm oil sold in major markets in Abia State, Nigeria. Agroscience. 2007; 6(2): 25-27.

[7]. Okonkwo SI, Ogbuneke RU. Assessment of level of adulteration in palm oil (Elaeis guineensis) within Ihiala Local Government Area of Anambra State of Nigeria. J. Basic Phys. Res. 2010; 1: 13-16.

[8]. Agbaire PO. Quality assessment of palm oil sold in some major markets in Delta State, Southern Nigeria. Afr. J. Food Sci. Technol. 2012; 3(9): 223226.

[9]. Olorunfemi MF, Oyebanji AO, Awoite TM, Agboola AA, Oyelakin MO, Alimi JP, et al. Quality assessment of palm oil on sale in major markets of Ibadan, Nigeria. IJFR 1. 2014; 1: 8-15.

[10]. Enemuor SC, Adegoke SA, Haruna AO, Oguntibeju OO. Environmental and fungal contamination of palm oil sold in Anyigba Market, Nigeria. Afr. J. Microbiol. Res. 2012; 6(11): 2744-2747.

[11]. Ohimain EI, Daokoru-Olukole C, Izah SC, Alaka EE. Assessment of the quality of crude palm oil produced by smallholder processors in Rivers State, Nigeria. Nigerian J. Agric. Food Environ. 2012; 8(2): 28-34.

[12]. Bharathi P, Elavarasi N, Mohansundaram S. Studies on rate of biodegradation of vegetable (coconut) oil by using Pseudomonas aeruginosa. International Journal of Environmental Biology. 2012.

[13]. Pearson D .The Chemical Analysis of Food. 8th edn. JA Churchill, London.1981: p- 535.

[14]. Seiyaboh EI, Kigigha LT, Alagoa CT, Izah SC. Microbial Quality of Palm Oil Sold in Amassoma, Bayelsa State, Nigeria. Int J Pub Health Safe. 2018; 3: 153 .

[15]. Okechalu JN, Dashen MM, Lar PM, Okechalu B and Gushop T. Microbiological quality and chemical characteristics of palm oil sold within Jos Metropolis, Plateau State, Nigeria. J. Microbiol. Biotechn. Res. 2011; 1(2):
107-112.

[16]. Odoh CK, Tarfen YA, Orjiakor IP, Martins PE, Seibai BT, Akpi UK, et al. Assessment of mold contamination and physicochemical properties of crude palm oil sold in Jos, Nigeria. Food Science \& Nutrition published by Wiley Periodicals, Inc. 2016; 5(2): 310-316. PMID: 28265365.

[17]. Babatunde OA, Bello GS. Comparative Assessment of Some Physicochemical Properties of Groundnut and Palm Oils Sold Within Kaduna Metropolis, Nigeria. IOSR Journal of Applied Chemistry. 2016; 9(11): 2278-5736.

[18]. Olorunfemi MF, Oyebanji AO, Awoite TM, Agboola AA, Oyelakin MO, et al. Quality assessment of palm oil on sale in major markets of Ibadan, Nigeria. IJFR. 2014; 8-15.

[19]. Salunkhe DK, Chavan JK, Adsule RN, Kadam SS. World oil Seeds. Chemistry, Technology and utilization. Van Nostrand Reinhold, New York. 1992; 54.

[20]. Tagoe SMA. Effect of mycotoxigenic microorganisms on palm fruits and palm oil produced at the cottage industry level. Nottingham University, United Kingdom, PHD Thesis. 2008.

[21]. Tagoe SMA, Dickson MJ, Apetorgbor MM. Factors influencing quality of palm oil produced at the cottage industry level in Ghana. International food Research Journal. 2012; 19(1):271-278.

[22]. Molokwu CN, Okpokwasili GC. Biodeterioration potential of fungi isolates from vegetable oils. International Journal of food science and Nutrition. 1997; 48(4): 251-255.

[23]. SON. Standard Organization of Nigeria. Standards for Edible Refined Palm Oil and Its Processed form. 2000; 2-5.

[24]. NIS. Nigerian Industrial Standards. Standard for Edible Vegetable Oil. 1992; 5-12.

[25]. Alimentarius C. Codex general standard for food additives. Codex standard. 1995:192-95.

[26]. Ekpa OD, Ekpe UJ. Effect of Coconut Oil Concentration on the Melting point profile and Free Fatty Acid Formation of Palm Oil. Nig. J. Chem. Res. 1996; 1: 8-12.

[27]. Ekwenye UN. Chemical characteristics of palm oil bioderioration. Chemical Society for Experimental Biology. 2005; 18: 141-149. 